\title{
Use, not abuse, of science
}

\section{The first tentative steps towards a comprehensive policy on scientific integrity, to guide scientists and politicians, are being taken in the US. Progress is slow, but should be encouraged.}

The accusation was made loud and clear: the United States administration led by former president George W. Bush ignored scientific advice and even manipulated scientific data for political ends. An acute example ${ }^{1}$ was the disbanding in June 2003 of an independent technical advisory committee to the National Nuclear Security Administration (NNSA). Iraq had been invaded and Sadam Hussein was being hunted down; Osama bin Laden remained at large. The development of nuclear weapons for deeply buried targets - socalled bunker busters - had been called for in the Nuclear Posture Review of 2001, and the President's budget for the financial year 2004 provided funds for the necessary research. But physicists on the NNSA advisory committee were critical of the efficacy of such weapons and warned of huge radioactive fallout from their detonation. The committee was abolished, only two years after its inception.

That and a catalogue of other incidents, duly noted by organizations such as the Union of Concerned Scientists ${ }^{2}$, prompted a strong statement from the incoming Obama administration, promising change. On 9 March 2009, President Obama published a memorandum to the executive departments and agencies of government, on the subject of scientific integrity. "Science and the scientific process", it said, "must inform and guide decisions of my Administration on a wide range of issues." He gave Director of the Office of Science and Technology
Policy John Holdren the task of fleshing out his guiding principles - on appointments, decision-making, whistle-blowing - into a recommended policy implementation, within 120 days.

Holdren's own memorandum followed - not within 120 days, but on 17 December 2010. Running to only four pages of text, those who had so eagerly awaited the memo's publication were disappointed, after such a wait, that it was not more extensive, more detailed, more specific. Holdren had warned months earlier that the elaboration of Obama's principles for scientific integrity was proving "particularly challenging", and there has been plenty of speculation as to quite what the (political) hold-ups might have been. Although Holdren's memo puts some flesh on the bones of Obama's principles, it concludes that each department and agency must devise its own actions to develop and implement the policies of integrity.

Meanwhile, the ethos of political interference in the use and interpretation of science has been seen to persist with the new administration. In the aftermath of the Deepwater Horizon explosion in the Gulf of Mexico of April 2010, it became clear $^{3}$ that the White House had ignored calculations of the likely rate of oil leakage made by scientists at the National Oceanic and Atmospheric Association, in favour of lower estimates; and that the whole process for the approval of offshore drilling projects by the Minerals Management Service was flawed, several environmental issues having been circumvented in the case of Deepwater Horizon.

In June 2010, the Department of the Interior (DOI) broke up the Minerals Management Service, creating new agencies in its stead. The DOI was also first off the mark, last year, with a policy on scientific integrity - but one that met with criticism, particularly for its seeming lack of censure of political appointees who alter scientific data. The DOI policy document has since been revised and was re-released last month, to a warmer reception: Jeff Ruch of Public Employees for Environmental Responsibility hailed it ${ }^{4}$ as a "good faith effort", but also wondered, "will they have the courage to apply the new rules?"

They must. The clash of empirical fact with political will is inevitable: witness also the recent furore in the UK over scientific advice to government on the issue of drug classification ${ }^{5}$. However, the use of science in government with integrity must be established and maintained. The steps taken so far in this US campaign may be small and slow, but the effort will be well rewarded when government is based transparently based - on good science.

\footnotetext{
References

1. Union of Concerned Scientists Scientific Integrity in Policymaking 27 (2004).

2. www.ucsusa.org

3. http://go.nature.com/4UKneA

4. http://go.nature.com/JdZIwy

5. Nature Phys. 5, 851 (2009).
}

\section{Let's share}

\section{It's time to give serious consideration to the notion of job-sharing in science.}

Are current efforts to encourage the recruitment of women into science misdirected? Writing in Proceedings of the National Academy of Sciences, Stephen Ceci and Wendy Williams suggest that they are (http://go.nature.com/M1ct6f). They argue that too much focus on the reviewing, interviewing and hiring stages of a science career shackles the cause of women in science to the problems of the past. Better, they say, to address today's causes of under-representation by recognizing the "differences in resources attributable to choices" and instituting education and policy changes accordingly.

Meanwhile, in an article for Science Careers in the journal Science, former tenuretrack researcher Kathy Weston gives an honest appraisal of what she calls "the sad demise" of her career (http://go.nature.com/ytVszn). Her exhortation to women in science is to play the game that they are often so reluctant to engage in: do the networking, and above all find a mentor. "Every scientist", says Weston, "needs someone in a position of power who has faith in his or her abilities."
Weston also echoes Ceci and Williams' notion of 'resources attributable to choices' in her solid suggestion for the retaining of talented women scientists who have children: job-sharing. Weston recognizes that "science has to proceed quickly and efficiently, and that means not much allowance can be made for anyone who wants to work in the slow lane." Job-sharing with another mother-researcher could have meant that "as a team we would have retained our competitive edge and hence our enthusiasm." It's an idea that deserves serious consideration. 